\title{
PROBLEM NARASTANIA DŁUGU PUBLICZNEGO W POLSCE W KONTEKŚCIE NOWEGO SYSTEMU EMERYTALNEGO
}

\section{WSTĘP}

W 1998 roku rząd premiera Jerzego Buzka przeprowadził w Polsce reformę systemu emerytalnego. Polegała ona na zastąpieniu dotychczasowego mechanizmu repartycyjnego, nowym systemem repartycyjno-kapitałowym. Powstały powszechne towarzystwa emerytalne i zarządzane przez nie otwarte fundusze emerytalne tworząc drugi filar systemu zabezpieczeń społecznych dla osób w wieku poprodukcyjnym, w którym uczestnictwo większości pracujących obywateli naszej ojczyzny jest obowiązkowe.

Przeprowadzona na przełomie 1998 i 1999 roku reforma systemu emerytalnego w Polsce od kilku już lat budzi spore kontrowersje. Wybuch kryzysu finansowego, latem 2007 roku w Stanach Zjednoczonych, a następnie jego rozprzestrzenienie się na inne kraje oraz na realną sferę gospodarki, spowodował między innymi niespotykane perturbacje na krajowych i międzynarodowych rynkach finansowych oraz głęboką przeceną na przełomie 2008 i 2009 roku notowanych instrumentów finansowych. Jednocześnie zarówno w Polsce jak i zagranicą gwałtownie wzrosła skala deficytów budżetowych oraz szczególnego znaczenia nabrał problem lawinowo narastających długów publicznych prowadzących do niewypłacalności szeregu krajów rozwiniętych gospodarczo.

Celem artykułu jest przebadanie wpływu reformy systemu emerytalnego na problem deficytu budżetowego oraz narastania długu publicznego w Polsce.

Praca składa się z trzech części. Na początku krótko zaprezentowano podstawowe informacje charakteryzujące stan finansów publicznych w Polsce. W drugiej części pracy zanalizowano sposób funkcjonowania systemu emerytalnego po reformie dokonanej przez rząd premiera Jerzego Buzka. W końco- 
wej części artykułu przebadano wpływ nowego systemu emerytalnego na kreowanie deficytu budżetowego i długu publicznego. Opracowanie powstało na podstawie publicznie dostępnych danych źródłowych pochodzących z Komisji Nadzoru Finansowego, Ministerstwa Finansów, Narodowego Banku Polskiego, Giełdy Papierów Wartościowych w Warszawie oraz Głównego Urzędu Statystycznego i jest wynikiem wieloletnich zainteresowań autora.

\section{DEFICYT BUDŻETOWY I DŁUG PUBLICZNY W POLSCE}

W ciagu ostatnich dwunastu lat budżet państwa polskiego charakteryzował się ciągłym występowaniem deficytu (dane w tabeli 1). Szczególnie wysoki poziom przewagi wydatków nad dochodami wystąpił w latach 2001-2004 oraz po 2009 roku. Pierwszy z analizowanych okresów obejmował lata poprzedzające wstąpienie Polski do Unii Europejskiej. W czasie tym Polska szczególnie intensywnie dokonywała dostosowywania swojego prawa wewnętrznego oraz wielu procedur administracyjnych do standardów unijnych, co wiązało się z koniecznością ponoszenia dosyć dużych wydatków. Ponadto lata 2001-2002 były okresem istotnego spowolnienia wzrostu gospodarczego, którego tempo mierzone stopą wzrostu realnego produktu krajowego brutto spadło do zaledwie jednego procenta. Brak możliwości zredukowania wydatków publicznych z uwagi na ich sztywny charakter zaowocował wtedy gwałtownym wzrostem deficytu budżetowego zarówno w wymiarze bezwzględnym, jak i w ujęciu relatywnym - w relacji do produktu krajowego brutto (dane w tabeli 2). Od nazwiska ówczesnego ministra finansów sytuację tą nazwano „dziurą Bauca”.

Tabela 1. Podstawowe pozycje charakteryzujące stan budżetu Polski (w milionach złotych, ceny bieżące)

\begin{tabular}{|l|c|c|c|c|c|}
\hline \multicolumn{1}{|c|}{ ROK } & DOCHODY & WYDATKI & WYDATKI DO PKB & DEFICYT & DEFICYT DO PKB \\
\hline 1999 & 125922,2 & 138401,2 & $22,50 \%$ & $-12479,0$ & $-2,03 \%$ \\
\hline 2000 & 135663,9 & 151054,9 & $20,29 \%$ & $-15391,0$ & $-2,07 \%$ \\
\hline 2001 & 140526,9 & 172885,2 & $22,19 \%$ & $-32358,3$ & $-4,15 \%$ \\
\hline 2002 & 143519,8 & 182922,4 & $22,64 \%$ & $-39402,6$ & $-4,88 \%$ \\
\hline 2003 & 152176,0 & 189165,2 & $22,46 \%$ & $-36989,2$ & $-4,39 \%$ \\
\hline 2004 & 156290,2 & 197794,7 & $21,42 \%$ & $-41504,5$ & $-4,50 \%$ \\
\hline 2005 & 179801,6 & 208360,8 & $21,19 \%$ & $-28559,2$ & $-2,90 \%$ \\
\hline 2006 & 197673,5 & 222757,6 & $21,01 \%$ & $-25084,1$ & $-2,37 \%$ \\
\hline 2007 & 236367,5 & 252323,9 & $21,44 \%$ & $-15956,4$ & $-1,36 \%$ \\
\hline 2008 & 253547,3 & 277893,5 & $21,79 \%$ & $-24346,2$ & $-1,91 \%$ \\
\hline 2009 & 274183,5 & 298028,5 & $22,19 \%$ & $-23845,0$ & $-1,78 \%$ \\
\hline 2010 & 250302,8 & 294893,9 & $20,84 \%$ & $-44591,1$ & $-3,15 \%$ \\
\hline
\end{tabular}

Źródło: opracowanie własne na podstawie danych Ministerstwa Finansów: www.mf.gov.pl oraz Roczników Statystycznych GUS za lata 1999-2011. 
Tabela 2. Dług sektora general government (w milionach złotych, ceny bieżące)

\begin{tabular}{|c|c|c|}
\hline ROK & DtUG SEKTORA GENERAL GOVERNMENT & W RELACI DO PKB \\
\hline 1999 & 263391,6 & $42,82 \%$ \\
\hline 2000 & 273832,2 & $36,77 \%$ \\
\hline 2001 & 292817,5 & $37,58 \%$ \\
\hline 2002 & 340895,6 & $42,20 \%$ \\
\hline 2003 & 396730,7 & $47,11 \%$ \\
\hline 2004 & 422385,1 & $45,75 \%$ \\
\hline 2005 & 463018,3 & $47,09 \%$ \\
\hline 2006 & 506036,3 & $47,74 \%$ \\
\hline 2007 & 529369,8 & $44,99 \%$ \\
\hline 2008 & 600829,2 & $47,11 \%$ \\
\hline 2009 & 684073,0 & $50,92 \%$ \\
\hline 2010 & 776821,0 & $54,89 \%$ \\
\hline
\end{tabular}

Źródło: jak w tab. 1.

Drugi z analizowanych okresów obejmuje czas globalnego kryzysu gospodarczego, który rozpoczął się latem 2007 roku od załamania rynku kredytów hipotecznych w Stanach Zjednoczonych, a następnie rozprzestrzenił się na inne kraje i sektory gospodarki. Podobnie jak w wielu innych państwach, odpowiedzią na to spektakularne i głębokie załamanie gospodarcze stała się $\mathrm{w}$ Polsce, zgodnie $\mathrm{z}$ tradycyjnym keynesowskim podejściem, ekspansywna polityka budżetowa. W ramach przygotowań do mistrzostw Europy w piłce nożnej, które w 2012 roku odbyły się w Polsce, rząd premiera Donalda Tuska uruchomił program masowych inwestycji infrastrukturalnych, obejmujący swoim zasięgiem oprócz budowy stadionów, przede wszystkim wiele inwestycji komunikacyjnych: autostrady, trasy szybkiego ruchu, obwodnice miast, modernizowanie linii kolejowych wraz z infrastrukturą towarzyszącą itp. Konsekwencją takiej polityki gospodarczej, podobnie jak w innych krajach zachodnich, jest gwałtowny wzrost deficytu budżetowego, który od jakiegoś czasu budzi kontrowersje wśród liberalnych ekonomistów polskich. Długookresowym skutkiem utrzymywania się przewagi wydatków nad dochodami w Polsce jest wzrost długu publicznego. Szczególnie szybki wzrost relacji zadłużenia do produktu krajowego brutto wystąpił w latach 2001-2004 oraz po 2009 roku i pokrywa się z okresami dużych deficytów budżetowych, które są przede wszystkim finansowane zwiększonymi emisjami skarbowych papierów dłużnych. Zobowiązania te niewątpliwie obciążają przyszłe pokolenia Polaków oraz w świetle zapisów konstytucji i ustawy o finansach publicznych komplikują prowadzenie polityki gospodarczej przyszłym rządom. 


\section{CHARAKTERYSTYKA ZREFORMOWANEGO SYSTEMU EMERYTALNEGO}

Reforma emerytalna wprowadzona w życie w 1999 roku przez rząd premiera Jerzego Buzka polegała na zastąpieniu dotychczasowego repartycyjnego systemu zabezpieczeń społecznych nowym systemem mieszanym kapitałowo-repartycyjnym. W tym celu doprowadzono do powstania powszechnych towarzystw emerytalnych, które zarządzają otwartymi funduszami emerytalnymi. Zmiany w systemie zabezpieczeń społecznych objęły znaczną część obywateli opłacających składki w Zakładzie Ubezpieczeń Społecznych. Dla osób, które nie ukończyły w 1999 roku trzydziestego roku życia uczestnictwo w nowym systemie emerytalnym było generalnie obowiązkowe. Do końca 1999 roku osoby te miały obowiązek wyboru funduszu emerytalnego, do którego chciały przystąpić i podpisania z nim stosownej umowy. Jeśli tego nie zrobiły to w 2000 roku w drodze losowania przeprowadzonego przez Zakład Ubezpieczeń Społecznych były przydzielane do poszczególnych, działających otwartych funduszy emerytalnych, proporcjonalnie do ich ówczesnego udziału w rynku. $Z$ kolei osoby w wieku od trzydziestego do pięćdziesiątego roku życia miały możliwość wyboru pomiędzy nowym systemem emerytalnym a starym. Jeśli decydowały się na przystąpienie do nowego systemu emerytalnego, to również do końca 1999 roku musiały podpisać umowę z wybranym przez siebie otwartym funduszem emerytalnym. Jeśli natomiast chciały pozostać w starym systemie emerytalnym to nie podpisywały żadnej umowy $\mathrm{z}$ otwartymi funduszami emerytalnymi. Polacy powyżej pięćdziesiątego roku życia nie mieli możliwości wyboru i pozostawali w starym systemie emerytalnym. Począwszy od 2000 roku młodzi ludzie podejmujący pierwszą pracę zawodową, poza sektorem rolnym oraz poza służbami mundurowymi, wymiarem sprawiedliwości i innymi branżami cieszącymi się określonymi przywilejami emerytalnymi, zobowiązani są w ciągu 7 dni do wyboru funduszu emerytalnego oraz do podpisania $z$ nim stosownej umowy. Jeśli tego nie robią to są losowo przydzielani do działających na rynku otwartych funduszy emerytalnych przez Zakład Ubezpieczeń Społecznych, który co pewien czas organizuje w tym celu losowania, stosownie do zmieniających się przepisów prawnych regulujących ten obszar gospodarki.

W wyniku tzw. ubruttowienia wynagrodzeń w 1999 roku składki na ubezpieczenie emerytalne i rentowe $\mathrm{w}$ połowie płacone są przez pracodawcę, a w połowie przez pracownika. Oczywiście z ekonomicznego punktu widzenia cały ciężar tych składek spoczywa na pracodawcy i jest jednym $z$ najistotniejszych pozapłacowych kosztów pracy w Polsce. Składka emerytalna wynosząca standardowo 19,52\% płacy brutto trafia do dwóch filarów. Do ma- 
ja 2011 roku 12,22\% zasilało dotychczasowy system repartycyjny (tzw. I filar) obsługiwany przez Zakład Ubezpieczeń Społecznych. Z tych 12,22\%, 11,22\% zapisywanych było na indywidualnych kontach ubezpieczonych jako tzw. wirtualny kapitał, a 1\% zasilało Fundusz Rezerwy Demograficznej. Wirtualny kapitał z ekonomicznego punktu widzenia oczywiście nigdy nie istniał. Są to po prostu pieniądze pochodzące $z$ bieżących składek emerytalnych pracujących Polaków, które umożliwiają wypłatę rent i emerytur dzisiejszym świadczeniobiorcom. Pozostałe 7,3\%, z wynoszącej 19,52\% składki emerytalnej, przekazywane było przez Zakład Ubezpieczeń Społecznych do konkretnego otwartego funduszu emerytalnego, z którym ubezpieczony podpisał umowę (tzw. II filar). Wspomniane 19,52\% składki nie może być liczone od niższego poziomu wynagrodzeń w stosunku do ustawowo zdefiniowanej minimalnej podstawy wymiaru składek na ubezpieczenia społeczne, zdrowotne i Fundusz Pracy. Przykładowo w 2011 roku płaca minimalna w Polsce wynosiła 1386 złotych brutto, a minimalna podstawa wymiaru składek na wspomniane ubezpieczenia emerytalne i rentowe ustalona została na poziomie 2015,40 złotego (to jest 60\% przeciętnego miesięcznego prognozowanego wynagrodzenia brutto). Prawo definiuje również maksymalną roczną podstawę wymiaru składek na ubezpieczenia emerytalne i rentowe na poziomie 250\% przeciętnego prognozowanego miesięcznego wynagrodzenia brutto. Kwota ta w 2011 roku wynosiła 100770 złotych, co odpowiadało miesięcznym zarobkom w wysokości 8 397,50 zł ${ }^{1}$.

Tabela 3. Liczba rachunków i członków otwartych funduszy emerytalnych (na koniec roku)

\begin{tabular}{|c|c|c|}
\hline LATA & LICZBA RACHUNKÓW & LICZBA CZZONKÓW \\
\hline 1999 & - & 9665819 \\
\hline 2000 & 10734246 & 10419254 \\
\hline 2001 & 11007012 & 10637409 \\
\hline 2002 & 11468446 & 10989816 \\
\hline 2003 & 11967159 & 11463285 \\
\hline 2004 & 12533787 & 11979465 \\
\hline 2005 & 12139302 & 11720737 \\
\hline 2006 & 12826260 & 12353327 \\
\hline 2007 & 13643825 & 13134081 \\
\hline 2008 & 14364738 & 13823806 \\
\hline 2009 & 14977900 & 14360664 \\
\hline 2010 & 15491605 & 14930991 \\
\hline
\end{tabular}

Źródło: opracowanie własne na podstawie danych: Urzędu Nadzoru nad Funduszami Emerytalnymi, Komisji Nadzoru Ubezpieczeń i Funduszy Emerytalnych, Komisji Papierów Wartościowych i Giełd, Komisji Nadzoru Finansowego: www.knf.gov.pl.

${ }^{2}$ Opracowanie własne na podstawie danych Zakładu Ubezpieczeń Społecznych: www.zus.pl. 
Obok obowiązkowego uczestnictwa w otwartych funduszach emerytalnych, Polacy mogą na zasadzie pełnej dobrowolności i swobody decyzji oszczędzać na swoją przyszłą emeryturę w ramach trzeciego filaru systemu emerytalnego lub poza nim. W tym celu mogą przystępować do nieobowiązkowych pracowniczych programów emerytalnych, które mogą być prowadzone w różnych formach lub samodzielnie odkładać część swoich zarobków na indywidualnych kontach emerytalnych (tzw. III filar). Są to całkowicie dobrowolne, dodatkowe formy oszczędzania na przyszłą emeryturę.

W ten sposób doprowadzono w Polsce do powstania kapitałowej części sytemu zabezpieczeń społecznych. Przyszłe emerytury osób ubezpieczonych w tym systemie mają pochodzić przede wszystkim z II filaru. Państwo zagwarantowało jednak minimalny poziom przyszłych emerytur poprzez obowiązek dopłat z I filaru, gdyby wysokość przyszłej emerytury z II filaru okazała się być poniżej ustawowo zdefiniowanej minimalnej wartości. Sytuacje takie najprawdopodobniej dotyczyć będą obywateli mało zarabiających lub osób pozostających długo bez pracy. Ponadto, poprzez utworzony system nadzoru nad uczestnikami kapitałowego sektora ubezpieczeń społecznych i instytucję minimalnej stopy zwrotu, państwo sprawuje stałą kontrolę nad bieżącym funkcjonowaniem tego sektora gospodarki. W wyniku tych reform przyszły system emerytalny w Polsce ma stopniowo ewoluować w kierunku systemu mieszanego kapitałowo-repartycyjnego.

Tabela 4. Kwoty składek i odsetek przekazanych przez Zakład Ubezpieczeń Społecznych do otwartych funduszy emerytalnych (w milionach złotych, ceny bieżące)

\begin{tabular}{|c|c|c|c|c|}
\hline ROK & PRZEKAZANE SKKADKI & $\begin{array}{c}\text { PRZEKAZANE ODSETKI } \\
\text { OD SKLADEK }\end{array}$ & RAZEM & $\begin{array}{c}\text { PRZEKAZANE SKLADKI I ODSETKI } \\
\text { OD SKLADEK } \\
\text { W RELACI DO PKB }\end{array}$ \\
\hline 1999 & 2262,7 & 22,9 & 2285,6 & $0,37 \%$ \\
\hline 2000 & 7586,4 & 17,1 & 7603,5 & $1,02 \%$ \\
\hline 2001 & 8652,9 & 53,9 & 8706,9 & $1,12 \%$ \\
\hline 2002 & 9492,3 & 56,1 & 9548,3 & $1,18 \%$ \\
\hline 2003 & 10158,7 & 133,8 & 10292,6 & $1,22 \%$ \\
\hline 2004 & 11240,5 & 203,1 & 11443,6 & $1,24 \%$ \\
\hline 2005 & 13417,0 & 616,0 & 14033,0 & $1,43 \%$ \\
\hline 2006 & 15611,4 & 563,3 & 16174,7 & $1,53 \%$ \\
\hline 2007 & 17166,5 & 576,7 & 17743,2 & $1,51 \%$ \\
\hline 2008 & 20460,6 & 483,0 & 20943,6 & $1,60 \%$ \\
\hline 2009 & 21323,3 & 194,9 & 21518,2 & $1,64 \%$ \\
\hline 2010 & 22992,1 & 165,7 & 23157,8 & \\
\hline
\end{tabular}

Źródło: jak w tab. 3. 
Powstanie i rozpoczęcie działalności operacyjnej przez otwarte fundusze emerytalne w Polsce w 1999 roku zakończyło się dużym sukcesem. Znaczna liczba Polaków pomiędzy 30 a 50 rokiem życia zdecydowała się na przystąpienie do nowego systemu emerytalnego i tym samym opuszczenie starego systemu zabezpieczeń emerytalnych. Rzeczywista liczba pozyskanych członków przez otwarte fundusze emerytalne była bardzo duża i przekroczyła większość optymistycznych prognoz, które były wcześniej sporządzane. Już na starcie otwarte fundusze emerytalne miały ponad dziewięć i pół miliona klientów (dane w tabeli 3). Każdy kolejny miesiąc przynosi wzrost liczby członków otwartych funduszy emerytalnych. Wraz z podejmowaniem pierwszej legalnej pracy zawodowej poza sektorem rolnym większość Polaków ma obowiązek zapisania się do wybranego przez siebie otwartego funduszu emerytalnego. Dzięki temu liczba klientów tego systemu przez najbliższe kilkadziesiąt lat będzie rosnąć, tak że ostatecznie obejmie zdecydowaną większość obywateli naszego kraju pracujących poza rolnictwem. Spadek liczby rachunków i członków otwartych funduszy emerytalnych pomiędzy 2004 i 2005 roku wynikał głównie z rozpoczęcia procesu likwidacji tak zwanych martwych rachunków w funduszach. Są to rachunki obywateli nieżyjących, niepracujących poza rolnictwem, osób będących jednocześnie członkami kilku otwartych funduszy emerytalnych lub wreszcie ludzi w ogóle nie istniejących. Problem martwych rachunków powstał przy wdrażaniu reformy systemu emerytalnego w Polsce w 1999 i 2000 roku. Spowodowany był głównie licznymi nieprawidłowościami i nadużyciami mającymi wówczas miejsce.

Tabela 5. Aktywa netto otwartych funduszy emerytalnych (w milionach złotych, na koniec roku, ceny bieżące)

\begin{tabular}{|c|c|}
\hline ROK & AKTYWA NETTO \\
\hline 1999 & 4067,2 \\
\hline 2000 & 9500,0 \\
\hline 2001 & 19500,0 \\
\hline 2002 & 31564,6 \\
\hline 2003 & 44833,1 \\
\hline 2004 & 62626,9 \\
\hline 2005 & 86078,8 \\
\hline 2006 & 116563,3 \\
\hline 2007 & 140030,9 \\
\hline 2008 & 138261,4 \\
\hline 2009 & 178630,1 \\
\hline 2010 & 221251,1 \\
\hline
\end{tabular}

Źródło: jak w tab. 3. 
Powodzenie i bardzo duża popularność reformy systemu emerytalnego w 1999 roku skutkowały masowym przystępowaniem Polaków do otwartych funduszy emerytalnych. Powoduje to konieczność przekazywania większych sum pieniędzy przez Zakład Ubezpieczeń Społecznych na indywidualne rachunki ubezpieczonych prowadzone w otwartych funduszach emerytalnych (dane w tabeli 4) i przyczynia się do pogłębiania się wcześniej analizowanego problemu deficytu budżetowego i wzrostu długu publicznego, oraz skutkuje znaczącym wzrostem aktywów netto otwartych funduszy emerytalnych (dane w tabeli 5). Dzięki temu rola tych krajowych inwestorów instytucjonalnych bardzo szybko się zwiększa. Po kilkunastu latach aktywnej działalności na polskim rynku, otwarte fundusze emerytalne stały się ważnymi podmiotami krajowego rynku finansowego. Wraz z upływem czasu i dalszym wzrostem aktywów na skutek przekazywania kolejnych składek emerytalnych, ich rola będzie rosła i tak jak w innych rozwiniętych państwach świata staną się one jednymi z największych instytucjonalnych inwestorów na rynku kapitałowym.

Tabela 6. Struktura portfela inwestycyjnego otwartych funduszy emerytalnych (na koniec roku)

\begin{tabular}{|c|c|c|c|}
\hline ROK & SKARBOWE PAPIERY DLUŻNE & AKCJE & INNE \\
\hline 1999 & $67,7 \%$ & $30,9 \%$ & $1,4 \%$ \\
\hline 2000 & $63,0 \%$ & $33,7 \%$ & $3,3 \%$ \\
\hline 2001 & $68,5 \%$ & $28,3 \%$ & $3,2 \%$ \\
\hline 2002 & $66,9 \%$ & $27,9 \%$ & $5,2 \%$ \\
\hline 2003 & $60,7 \%$ & $31,9 \%$ & $7,4 \%$ \\
\hline 2004 & $58,4 \%$ & $32,5 \%$ & $9,1 \%$ \\
\hline 2005 & $62,5 \%$ & $32,1 \%$ & $5,4 \%$ \\
\hline 2006 & $62,4 \%$ & $34,4 \%$ & $3,2 \%$ \\
\hline 2007 & $60,0 \%$ & $34,9 \%$ & $5,1 \%$ \\
\hline 2008 & $73,5 \%$ & $21,6 \%$ & $4,9 \%$ \\
\hline 2009 & $61,6 \%$ & $30,5 \%$ & $7,9 \%$ \\
\hline 2010 & $52,4 \%$ & $36,4 \%$ & $11,2 \%$ \\
\hline
\end{tabular}

Źródło: jak w tab. 3.

W końcu 2010 roku wielkość całkowitych aktywów netto otwartych funduszy emerytalnych wynosiła 221,3 miliarda złotych. W akcje notowane na giełdzie warszawskiej instytucje te zainwestowały około 79,6 miliarda złotych stając się jednymi z największych i najważniejszych inwestorów giełdowych, lokując ponad 30\% swoich aktywów we własnościowe papiery wartościowe dopuszczone do publicznych obrotów giełdowych (dane w tabeli 6). Analiza struktury portfeli inwestycyjnych otwartych funduszy emerytalnych wyraźnie wskazuje, że instytucje te lokują zarządzane przez siebie środki przede wszyst- 
kim w dłużne skarbowe papiery wartościowe i akcje notowane na giełdzie warszawskiej. Jeśli chodzi o instrumenty własnościowe są to przede wszystkim akcje największych firm notowanych na Giełdzie Papierów Wartościowych w Warszawie, charakteryzujące się dużą płynnością. Są to głównie akcje spółek wchodzących w skład indeksu WIG202.

\section{SZACUNKOWY UDZIAt ZREFORMOWANEGO SYSTEMU EMERYTALNEGO W KREOWANIU DEFICYTU BUDŻETOWEGO I DŁUGU PUBLICZNEGO}

Konsekwencje reformy systemu emerytalnego w Polsce są długofalowe i obejmują wiele dziedzin życia. $Z$ punktu widzenia finansów publicznych reforma emerytalna pogłębiła deficyt budżetowy oraz deficyt całego sektora finansów publicznych w naszej ojczyźnie i przyczynia się do narastających problemów z wypełnieniem kryteriów związanych z ewentualnym przyszłym przystąpieniem do Strefy Euro. Co miesiąc Zakład Ubezpieczeń Społecznych przelewa wielomilionowe kwoty pieniędzy do otwartych funduszy emerytalnych na rachunki osób ubezpieczonych, uczestniczących w nowym systemie emerytalnym. W 2010 roku ten comiesięczny transfer osiągnął rozmiary prawie dwóch miliardów złotych, co w skali roku stanowi około 1,5-1,6\% produktu krajowego brutto. Ubytek ten musi być rekompensowany większymi dotacjami budżetowymi, ponieważ jednocześnie Zakład Ubezpieczeń Społecznych wypłaca renty i emerytury dotychczasowym świadczeniobiorcom. Przyczynia się to niewątpliwie do narastania deficytów budżetowych i długu publicznego. Budżet musi przekazywać większe dotacje Zakładowi Ubezpieczeń Społecznych, aby ten mógł wywiązywać się ze swoich bieżących zobowiązań wobec dzisiejszych i przyszłych emerytów. Jednocześnie Zakład Ubezpieczeń Społecznych przelewa część otrzymywanych składek emerytalnych do otwartych funduszy emerytalnych, które to z kolei znaczną część otrzymanych środków (50-60\%) inwestują $\mathrm{w}$ krajowe skarbowe papiery dłużne, służące finansowaniu narastających deficytów budżetowych i długu publicznego (rysunek 1). W ten sposób z makroekonomicznego punktu widzenia sektora finansów publicznych częściowo zamyka się sposób funkcjonowania mechanizmu nowego systemu emerytalnego w Polsce, który nieuchronnie pogłębia deficyt budżetowy i zwiększa dług publiczny wpychając naszą ojczyznę w narastającą spiralę zadłużenia powodującą powstawanie ryzyka niewypłacalności całego kraju.

\footnotetext{
${ }^{3} \mathrm{Na}$ podstawie danych Komisji Nadzoru Finansowego: www.knf.gov.pl.
} 


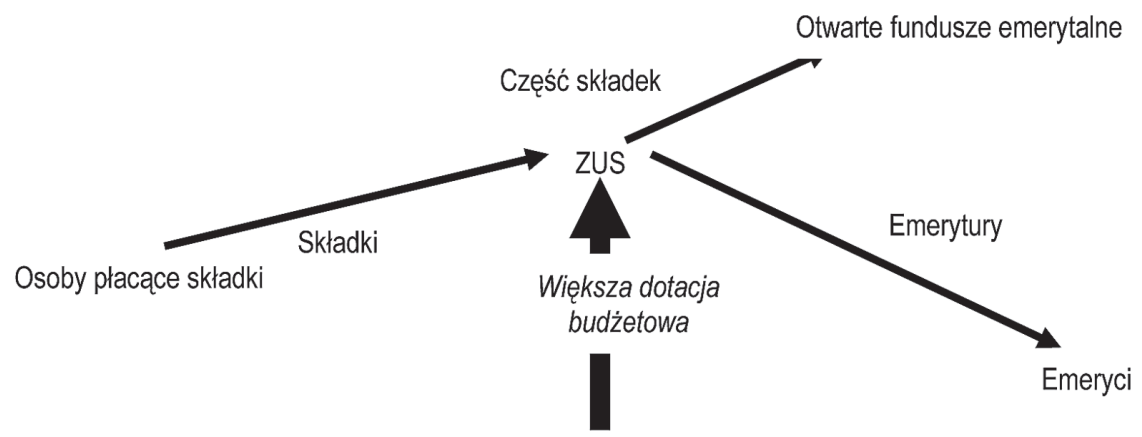

Budżet

Rysunek 1. Schemat nowego systemu emerytalnego po reformie Źródło: opracowanie własne.

$\mathrm{Z}$ punktu widzenia stanu finansów publicznych twórcy reformy systemu emerytalnego w końcu lat 90. XX wieku wykazali dużą krótkowzroczność. Wielokrotnie wygłaszane wtedy opinie mówiące, że wpływy z prywatyzacji pozwolą bez problemów na sfinansowanie reformy emerytalnej okazały się całkowicie błędne.

Kwestie te są obecnie newralgiczne $z$ punktu widzenia wypełnienia kryteriów konwergencji z Maastricht i ewentualnego przyszłego przystąpienia Polski do Strefy Euro. Kryterium fiskalne zakłada, że relacja deficytu instytucji rządowych i samorządowych (tzn. sektor general government), liczona według metodologii unijnej, do produktu krajowego brutto nie może przekroczyć wartości referencyjnej wynoszącej 3\% oraz dług sektora tych instytucji powinien utrzymywać się $\mathrm{w}$ relacji do produktu krajowego brutto na poziomie nieprzekraczającym 60\%. Po wieloletnich negocjacjach prowadzonych przez kolejne rządy ostatecznie w końcu 2010 roku Komisja Europejska i Eurostat nie zgodziły się, aby transfery przekazywane do otwartych funduszy emerytalnych nie były uwzględniane przy obliczaniu deficytu budżetowego i długu publicznego. Tym samym Polska, tak jak kilka innych krajów członkowskich Unii Europejskiej z Europy Środkowej i Wschodniej, została niejako ukarana za przeprowadzenie reformy systemu emerytalnego i ujawnianie realnie istniejących zobowiązań emerytalnych w sprawozdawczości finansów publicznych w kontekście narastających problemów starzejących się społeczeństw w państwach europejskich. To nierówne traktowanie krajów, które zdecydowały się na przeprowadzenie reformy swoich systemów emerytalnych w stosunku do państw, które takich zmian nie dokonały było koronnym argumentem Polski na rzecz zmiany metodologii obliczania deficytu budżetowego i długu publicznego przez Eurostat w krajach, które zreformowały swoje systemy eme- 
rytalne i w związku $\mathrm{z}$ tym ujawniają istniejące $\mathrm{z}$ tego tytułu zobowiązania. Druga strona tego sporu - Komisja Europejska, podnosiła nie bez racji, że skoro środki przekazywane do otwartych funduszy emerytalnych i znajdujące się na indywidualnych kontach emerytalnych w kapitałowym filarze systemu zabezpieczeń emerytalnych podlegają dziedziczeniu, to nie mogą być zaliczane do sektora finansów publicznych i w związku z tym nie mogą być odliczane w kolejnych latach od deficytów budżetowych i długu publicznego. Twarde stanowisko Unii Europejskiej w tej sprawie przesądziło ostatecznie o porażce krajów, z Polską na czele, które przeprowadziły reformy emerytalne i domagały się zmiany metodologii liczenia deficytów budżetowych i długów publicznych w tych państwach.

Stojąc wobec tych faktów, wypełnienie fiskalnego kryterium konwergencji w kontekście ewentualnego przyszłego wstąpienia Polski do Strefy Euro, bez dokonania istotnych zmian w istniejącym do maja 2011 roku systemie emerytalnym było właściwie nierealne. Wartość rocznych transferów przekazywanych do otwartych funduszy emerytalnych osiągnęła w ostatnich latach rozmiary 1,5-1,6\% produktu krajowego brutto i wykazywała tendencję rosnącą. Oznaczało to, że chcąc spełnić kryterium konwergencji nakazujące utrzymywanie deficytu sektora instytucji rządowych i samorządowych w relacji do produktu krajowego brutto na poziomie nie wyższym niż 3\%, Polska tak naprawdę musiałaby utrzymywać ten deficyt na poziomie niższym niż 1,4\% produktu krajowego brutto, ponieważ resztę deficytu generowała reforma emerytalna z 1999 roku skutkująca przekazywaniem części składek przez Zakład Ubezpieczeń Społecznych poza sektor instytucji "general government” (dane w tabelach 7 i 8). Osiagnięcie takiej sytuacji było z politycznej i ekonomicznej perspektywy właściwie niemożliwe. Stało to również w jawnej sprzeczności wobec polityki gospodarczej realizowanej w większości krajów członkowskich, które reagując na kryzys finansowo-gospodarczy ostatnich lat zastosowały keynesowską zasadę ekspansywnej polityki fiskalnej zwiększając deficyty budżetowe i wydatki publiczne.

Nieprzeprowadzenie zmian w istniejącym w Polsce systemie emerytalnym przy niezmienionej metodologii obliczania deficytu budżetowego i długu publicznego doprowadziłoby również w niedalekiej przyszłości do przekroczenia drugiego (55\%) i trzeciego (60\%) progu ostrożnościowego relacji państwowego długu publicznego do produktu krajowego brutto, jak również do niespełnienia fiskalnego kryterium konwergencji mówiącego o utrzymywaniu zadłużenia sektora instytucji rządowych i samorządowych (general government) na poziomie nieprzekraczającym $60 \%$ produktu krajowego brutto. Mogło to stanowić barierę realizacji jakiejkolwiek aktywnej polityki gospodarczej dla kolejnych rządów wobec istniejących zapisów obowiązującej w naszej ojczyźnie konstytucji i ustawy o finansach publicznych. 
Tabela 7. Deficyt budżetowy w kontekście transferów do otwartych funduszy emerytalnych (w milionach złotych, ceny bieżące)

\begin{tabular}{|c|c|c|c|c|}
\hline RoK & $\begin{array}{c}\text { DEFICYT } \\
\text { BUDŻETOWY }\end{array}$ & $\begin{array}{c}\text { DEFICYT } \\
\text { DO PKB }\end{array}$ & $\begin{array}{c}\text { DEFICYT BUDŻETOWY } \\
\text { POMNIESZONY O TRANSFERY } \\
\text { DO OTWARTYCH FUnDUSZY EMERYTALNYCH }\end{array}$ & $\begin{array}{c}\text { DeFICYT BUDŻETOWY POMNIESZONY } \\
\text { O TRANSFERY } \\
\text { DO OTWARTYCH FUNDUSZY EMERYTALNYCH } \\
\text { W RELACI DO PKB }\end{array}$ \\
\hline 1999 & $-12479,0$ & $-2,03 \%$ & $-10193,40$ & $-1,66 \%$ \\
\hline 2000 & $-15391,0$ & $-2,07 \%$ & $-7787,50$ & $-1,05 \%$ \\
\hline 2001 & $-32358,3$ & $-4,15 \%$ & $-23651,40$ & $-3,04 \%$ \\
\hline 2002 & $-39402,6$ & $-4,88 \%$ & $-29854,30$ & $-3,70 \%$ \\
\hline 2003 & $-36989,2$ & $-4,39 \%$ & $-26696,60$ & $-3,17 \%$ \\
\hline 2004 & $-41504,5$ & $-4,50 \%$ & $-30060,90$ & $-3,26 \%$ \\
\hline 2005 & $-28559,2$ & $-2,90 \%$ & $-14526,20$ & $-1,48 \%$ \\
\hline 2006 & $-25084,1$ & $-2,37 \%$ & $-8909,40$ & $-0,84 \%$ \\
\hline 2007 & $-15956,4$ & $-1,36 \%$ & 1786,80 & $0,15 \%$ \\
\hline 2008 & $-24346,2$ & $-1,91 \%$ & $-3402,60$ & $-0,27 \%$ \\
\hline 2009 & $-23845,0$ & $-1,78 \%$ & $-2326,80$ & $-0,17 \%$ \\
\hline 2010 & $-44591,1$ & $-3,15 \%$ & $-21433,30$ & $-1,51 \%$ \\
\hline
\end{tabular}

Źródło: opracowanie własne na podstawie danych: Ministerstwa Finansów: www.mf.gov.pl, Urzędu Nadzoru nad Funduszami Emerytalnymi, Komisji Nadzoru Ubezpieczeń i Funduszy Emerytalnych, Komisji Papierów Wartościowych i Giełd, Komisji Nadzoru Finansowego: www.knf.gov.pl oraz Roczników Statystycznych GUS za lata 1999-2011.

Tabela 8. Udział transferów do otwartych funduszy emerytalnych w kreowaniu deficytu budżetowego (w milionach złotych, ceny bieżące)

\begin{tabular}{|c|c|c|c|}
\hline RoK & $\begin{array}{c}\text { DEFICYT } \\
\text { BUDŻETOWY }\end{array}$ & $\begin{array}{c}\text { TRANSFERY } \\
\text { DO OtWARTYCH FUNDUSZY EMERYTALNYCH }\end{array}$ & $\begin{array}{c}\text { UdZIAL TRANSFERÓW DO OTWARTYCH FUNDUSZY EMERYTALNYCH } \\
\text { W KREOWANIU DEFICYTU BUDŻETOWEGO }\end{array}$ \\
\hline 1999 & $-12479,0$ & 2285,6 & $18,32 \%$ \\
\hline 2000 & $-15391,0$ & 7603,5 & $49,40 \%$ \\
\hline 2001 & $-32358,3$ & 8706,9 & $26,91 \%$ \\
\hline 2002 & $-39402,6$ & 9548,3 & $24,23 \%$ \\
\hline 2003 & $-36989,2$ & 10292,6 & $27,83 \%$ \\
\hline 2004 & $-41504,5$ & 11443,6 & $27,57 \%$ \\
\hline 2005 & $-28559,2$ & 14033,0 & $49,14 \%$ \\
\hline 2006 & $-25084,1$ & 16174,7 & $64,48 \%$ \\
\hline 2007 & $-15956,4$ & 17743,2 & $111,20 \%$ \\
\hline 2008 & $-24346,2$ & 20943,6 & $86,02 \%$ \\
\hline 2009 & $-23845,0$ & 21518,2 & $90,24 \%$ \\
\hline 2010 & $-44591,1$ & 23157,8 & $51,93 \%$ \\
\hline
\end{tabular}

Źródło: Opracowanie własne na podstawie danych: Ministerstwa Finansów: www.mf.gov.pl, Urzędu Nadzoru nad Funduszami Emerytalnymi, Komisji Nadzoru Ubezpieczeń i Funduszy Emerytalnych, Komisji Papierów Wartościowych i Giełd, Komisji Nadzoru Finansowego: www.knf.gov.pl. 
Warto zauważyć, że gdyby Komisja Europejska zgodziła się zmienić metodologię obliczania deficytu budżetowego i pozwoliła odliczać składki i odsetki od składek przekazywane do otwartych funduszy emerytalnych od jego wielkości, to poziom deficytu budżetowego i całego deficytu sektora finansów publicznych w Polsce w ostatnich latach wyglądałby zupełnie inaczej. Wartość tak liczonego deficytu budżetowego w relacji do produktu krajowego brutto utrzymywała się w latach 2006, 2008-2009 poniżej 1\%, notując w 2007 roku nawet nadwyżkę (dane w tabeli 7). Zmieniłoby to całkowicie wykazywany publicznie statystyczny obraz stanu budżetu państwa i całego sektora finansów publicznych. Transfery do otwartych funduszy emerytalnych odpowiadają w ostatnich latach za zdecydowaną większość całego deficytu budżetowego (dane w tabeli 8).

Tabela 9. Dług sektora general government pomniejszony o transfery do otwartych funduszy emerytalnych (w milionach złotych, ceny bieżące)

\begin{tabular}{|c|c|c|c|c|c|}
\hline RoK & $\begin{array}{c}\text { DLUG SEKTORA } \\
\text { GENERAL GOVERNMENT }\end{array}$ & $\begin{array}{c}\text { W RELACI } \\
\text { DO PKB }\end{array}$ & $\begin{array}{c}\text { SKUMULOWANE TRANSFERY } \\
\text { DO OTWARTYCH } \\
\text { FUNDUSZY EMERYTALNYCH }\end{array}$ & $\begin{array}{c}\text { DEUG SEKTORA GENERAL GOVER- } \\
\text { NMENT POMNIEISZONY O TRANSFE- } \\
\text { RY DO OTWARTYCH FUNDUSZY EME- } \\
\text { RYTALNYCH }\end{array}$ & $\begin{array}{c}\text { W RELACI } \\
\text { DO PKB }\end{array}$ \\
\hline 1999 & 263391,6 & $42,82 \%$ & 2285,6 & 261106,0 & $42,45 \%$ \\
\hline 2000 & 273832,2 & $36,77 \%$ & 9889,1 & 263943,1 & $35,45 \%$ \\
\hline 2001 & 292817,5 & $37,58 \%$ & 18596,0 & 274221,5 & $35,19 \%$ \\
\hline 2002 & 340895,6 & $42,20 \%$ & 28144,3 & 312751,3 & $38,71 \%$ \\
\hline 2003 & 396730,7 & $47,11 \%$ & 38436,9 & 358293,8 & $42,55 \%$ \\
\hline 2004 & 422385,1 & $45,75 \%$ & 49880,5 & 372504,6 & $40,35 \%$ \\
\hline 2005 & 463018,3 & $47,09 \%$ & 63913,5 & 399104,8 & $40,59 \%$ \\
\hline 2006 & 506036,3 & $47,74 \%$ & 80088,2 & 425948,1 & $40,18 \%$ \\
\hline 2007 & 529369,8 & $44,99 \%$ & 97831,4 & 431538,4 & $36,67 \%$ \\
\hline 2008 & 600829,2 & $47,11 \%$ & 118775,0 & 482054,2 & $37,80 \%$ \\
\hline 2009 & 684073,0 & $50,92 \%$ & 140293,2 & 543779,8 & $40,48 \%$ \\
\hline 2010 & 776821,0 & $54,89 \%$ & 163451,0 & 613370,0 & $43,34 \%$ \\
\hline
\end{tabular}

Źródło: opracowanie własne na podstawie danych: Ministerstwa Finansów: www.mf.gov.pl, Urzędu Nadzoru nad Funduszami Emerytalnymi, Komisji Nadzoru Ubezpieczeń i Funduszy Emerytalnych, Komisji Papierów Wartościowych i Giełd, Komisji Nadzoru Finansowego: www.knf.gov.pl oraz Roczników Statystycznych GUS za lata 1999-2011.

Warto również podkreślić, że włączenie otwartych funduszy emerytalnych do sektora instytucji rządowych i samorządowych (general government), o co nieskutecznie postulowała Polska wraz z kilkoma innymi krajami członkowskimi Unii Europejskiej z Europy Środkowej, pozwoliłoby zmniejszyć statystycznie wykazywany dług publiczny o około 163 miliardy złotych, z prawie $55 \%$ do około $43 \%$ produktu krajowego brutto (dane w ta- 
beli 9). Otwartą kwestią jest jednak czy zmieniłoby to postrzeganie Polski przez rynki finansowe, gdzie od wielu już lat występujemy w roli dużego kredytobiorcy i dłużnika i czy nie zostałoby to potraktowane jako jeszcze jedna forma „kreatywności” księgowej na poziomie makroekonomicznym.

\section{ZAKOŃCZENIE}

Przeprowadzona w 1999 roku reforma systemu emerytalnego w Polsce polegająca na stopniowym zastępowaniu repartycyjnego systemu zabezpieczeń społecznych nowym systemem kapitałowo-repartycyjnym okazała się wyjątkowo kosztowna dla sektora finansów publicznych. Transfery do otwartych funduszy emerytalnych osiagnęły w ostatnich latach rozmiary ponad dwudziestu miliardów złotych (około 1,5-1,6\% produktu krajowego brutto) poważnie przyczyniając się do wzrostu deficytów budżetowych oraz skutkując istotnym zwiększeniem się długu publicznego. Utrzymywanie takiego kształtu funkcjonowania systemu emerytalnego w Polsce właściwie uniemożliwiałoby wypełnienie kryteriów konwergencji z Mastricht i w konsekwencji ewentualne przyszłe wejście do Strefy Euro. Doprowadziłoby również w niedalekiej przyszłości do nieuchronnego przekraczania kolejnych progów ostrożnościowych, zawartych w ustawie o finansach publicznych, oraz limitu relacji długu publicznego do produktu krajowego brutto wynikającego $\mathrm{z}$ konstytucji. Stąd, pomimo sprzeciwu wielu środowisk liberalnych, wyniknęła obiektywna konieczność dokonania poważnej modyfikacji zreformowanego w 1999 roku systemu zabezpieczeń społecznych, przez rząd premiera Donalda Tuska. Zmiany te ostatecznie weszły w życie w maju 2011 roku.

\section{BIBLIOGRAFIA}

Dybał M., Efektywnośc inwestycyjna funduszy emerytalnych, CeDeWu, Warszawa 2008. Góra M., Integralny charakter systemu emerytalnego w Polsce: jeszcze raz o „Bezpieczeństwie dzięki różnorodności”, Fundacja Forum Obywatelskiego Rozwoju, Warszawa 2009. Góra M., System emerytalny, Polskie Wydawnictwo Ekonomiczne, Warszawa 2003. Jackowicz K., Kowalewski O., Crisis, internal governance mechanism and pension fund performance: Evidence from Poland, Emerging Markets Review, vol. 13, issue 4. Muszalski W., Ubezpieczenie spoteczne: podręcznik akademicki, PWN, Warszawa 2004. Orenstein M. A., Privatizing Pensions. The Transnational Campaign for Social Security Reform, Princeton University Press, Princeton, N.J. 2008.

Roczniki Statystyczne Gtównego Urzędu Statystycznego za lata 1999-2011.

Sowiński T., Finanse ubezpieczeń emerytalnych, Wolters Kluwer, Warszawa 2009. 
Szczepański M., Dylematy reformy polskiego systemu emerytalnego, Wydawnictwo Politechniki Poznańskiej, Poznań 2006.

www.gpw.com.pl - Giełda Papierów Wartościowych w Warszawie.

www.knf.gov.pl - Komisja Nadzoru Finansowego.

www.mf.gov.pl - Ministerstwo Finansów.

www.nbp.pl - Narodowy Bank Polski.

www.stat.gov.pl - Główny Urząd Statystyczny.

www.zus.pl - Zakład Ubezpieczeń Społecznych.

\title{
PROBLEM NARASTANIA D $Ł U G U$ PUBLICZNEGO W POLSCE W KONTEKŚCIE NOWEGO SYSTEMU EMERYTALNEGO
}

\section{STRESZCZENIE}

Artykuł analizuje wpływ zreformowanego w 1999 roku systemu zabezpieczeń społecznych na stan finansów publicznych w Polsce. Przebadano wpływ transferów do otwartych funduszy emerytalnych na kreowanie deficytu budżetowego i długu publicznego w kontekście kryteriów konwergencji z Maastricht.

\section{INCREASING PUBLIC DEBT ISSUE IN POLAND IN THE CONTEXT OF NEW PENSION SYSTEM}

\author{
SUMMARY
}

The article analyses the impact of the social security system reformed in 1999 on the state of public finance in Poland. The influence of public transfers to pension funds on the creation of budget deficit and public debt was studied in the context of the Maastricht convergence criteria. 
